УДК: $130.2+37.03$

\title{
Panos ELIOPOULOS
}

University of Peloponnese

ksatriya@tri.forthnet.gr

\section{MASS CULTURE, EDUCATION AND THE PERSPECTIVE OF INDIVIDUALITY}

For Adorno and Horkheimer, rationalism - in fact, a technical rationalism which becomes a rationalism of domination-failed to provide the path to the liberation

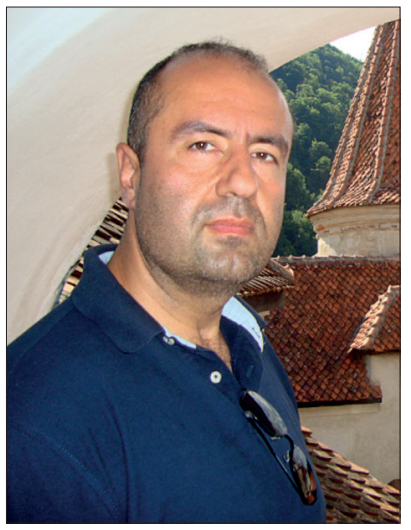
of man and society. The aftermath, half education of the masses, is not an incomplete education or lack of education, but substantially hostility towards culture and genuine education, decay and involvement of education in individual considerations and benefits, with the contribution of mass dissemination of culture and art. Half education is the spread of culture and art without a living relationship with the consciousness of people, without consequences for their lives. Adorno clarifies that in this context, the relationship between life and production reduces the former into the transitory epiphenomenon of the latter, as life and individual existence are not known in their immediacy, they do not connect directly, but they rather become part of the teaching for of material production. For Ortega y Gasset, a new type of human being has been born, the massman, who becomes isolated, trapped in the irrational feeling that nothing else, apart from his own private welfare, matters, but he also continues to demand as if it were his natural right to do so. Nonetheless, and although he remains an individualist, he does not have real access to the gifts of individuality. Marcuse understands that, ultimately, there is a conflict between production and profit on the one hand and selfdetermination on the other. As technology spreads its dominance over nature, man conquers man through mass control, diffused through work and culture. In this way, technological rationalism becomes ultimately political rationalism.

Keywords: Adorno, Horkheimer, Ortega y Gasset, Marcuse, mass culture, production, education, individuality.

For thinkers like Theodor Adorno, Max Horkheimer, Ortega y Gasset and Herbert Marcuse, the link between society and education comprises a problematic area. Apart from the «clarified content» to be taught, which for Adorno constitutes an undeniable civic fraud, the main concern is about the clearness and final filtration of knowledge as a culture within the social body. In the Dialectic of Enlightenment both Theodor Adorno and Max Horkheimer pose again the theoretical question which had earlier been highlighted by Schiller: 
"Why humanity, instead of entering a truly human stage, is sinking into a new kind of barbarism?"

For Adorno and Horkheimer, rationalism -in fact, a technical rationalism which becomes a rationalism of domination- failed to provide the path to the liberation of man and society ${ }^{1}$. In the essay Theory of Half - Education, Adorno expresses essential observations about the loss of intellectual prerequisites and aims at education through which the subject should be rationally formed according to the declarations of the Enlightenment. Progressive enlightenment thought aimed to replace the judgement of experience with reasoned judgement, but when its general education had degenerated to half-education, experienced judgement was replaced by 'selective, non-committal, exchangeable, and ephemeral knowledge,' the elements of which are likely to be almost immediately replaced by other information ${ }^{2}$. Instead of the coherence of generally shared life experiences, individuals respond and relate to life as it presents itself without either the old capacity for judgement or the liberal capacities that were its intended replacement. Instead of exercising judgement, individual,; are equipped only to respond and relate to things as they are without questioning.

Through his essay, the philosopher of the Frankfurt School develops his views on the crisis of education as a historical phenomenon - aftereffect of our technological civilization. As an evolution of previous pedagogical historical events, the half education of the masses is not an incomplete education or lack of education, but substantially hostility towards culture and genuine education, decay and involvement of education in individual considerations and benefits, with the contribution of mass dissemination of culture and art. Half education is the spread of culture and art without a living relationship with the consciousness of people, without consequences for their lives. The half educated man is not willing to challenge his educational space, namely the status quo in which he contemplates and lives. This means that the instrumental approach to education, an instrumental literacy in essence, in the form of the acquisition of adequate management skills in order to meet market needs, and also the university level professional specialization and fragmentation of knowledge, inactivate the critical faculties of the subjects involved and become part of the mechanisms of self preservation and reproduction of the social structures which support them.

According to Adorno, even the lack of education as mere benightedness or ignorance, in the past, allowed a direct relationship with objects and it was possible to develop into a critical consciousness. The disenchantment of the

\footnotetext{
${ }^{1}$ Adorno Th., Minima Moralia, transl. L. Anagnostou, 2nd edition Alexandreia, Athens 2000, passim.

${ }^{2}$ Adorno Theodor, I theoria tis imimorfosis [Theory of "Half - Education"], transl. L. Anagnostou, Alexandreia, Athens 2000, p. 11.
} 
world ultimately leads to the condition of absence of images, of culturelessness (Bilderlosigkeit), to the atrophy of spirit through its instrumentalization, to a desolation of spirit which is turned into a simple means1. Nothing keeps the spirit in a vital relation to ideas any longer. Due to "Bilderlosigkeit", the person who has half educating needs resorts to cultural products, through the multitude of cultural goods offered by mass media, which will provide a "seeming template of education". For Adorno, education cannot serve practical purposes, cannot be regarded as "socially useful work", due to the fact that in those case it will end up as a sacrilege ${ }^{2}$. Similarly, he upholds that to the extent that in the idea of education there lie elements of expedience, these elements should be able to make individuals affirm themselves as reasonable and free beings, in a reasonable and free society, and this is best achieved if everyone is educated for himself3.

The ruling class and the ruling elite, in an attempt to determine the economic, political and social management of society, promote their positions claiming that this is the best and the only way for the people and society to prosper. In reality, however, their purpose, as Adorno remarks, is half education of a large part of the population to the extent where the absolutist culture requires obedience and the compliance of mass consensus. To achieve this, they activate a personalized curriculum through educational policy that not only adapts and adjusts learners, but also determines who will be the future supervisors of the unequal distribution of economic resources with the ultimate goal of the reproduction of the narcissistic satisfaction of the masses and the one-sided gathering of power. Under this program, public education maintains an orientation, which was established by consolidating the market economy, which brutally favors discrimination between people: thus, ensuring the recycling of knowledge. In Minima Moralia, Adorno clarifies that in this context, the relationship between life and production reduces the former into the transitory epiphenomenon of the latter, as life and individual existence are not known in their immediacy, they do not connect directly, but they rather become part of the teaching for of material production ${ }^{4}$.

${ }^{1}$ Adorno Th., I theoria tis imimorfosis [Theory of "Half - Education"], transl. L. Anagnostou, Alexandreia, Athens 2000, pp. 49 - 50.

2 Adorno Th., I theoria tis imimorfosis [Theory of "Half - education], transl. L. Anagnostou, Alexandreia, Athens 2000, p. 35.

${ }^{3}$ Adorno Th., I theoria tis imimorfosis [Theory of "Half - education], transl. L. Anagnostou, Alexandreia, Athens 2000, p. 35.

${ }^{4}$ Adorno Th., Minima Moralia, transl. L. Anagnostou, 2nd edition Alexandreia, Athens 2000, p. 77. 
Noteworthy is the fact that uninhibited access to scientific education is the main road leading to half education ${ }^{1}$. The language of half education is nothing more than a patchwork of automatizations which are vacant of meaning and technocratic expressions derived mainly from the financial and administrative protocol, for the sake of which any form of critical thinking has been abandoned. As a result, in the half-education of mass culture everybody participates in the public discourse, everybody expresses opinions, but these are nothing but the echo of the "master's voice" for the reason that "the half educated are also compliant". ${ }^{2}$

Citizens enthusiastically accept cultural values promoted by this half - education program without critically considering critically the values of the market economy, which are a priori attached and confirmed by what is said to be "rational", reasonable and proper. These are a "mechanical reproducibility" and its "universally binding nature", the Dialectic of Enlightenment. In this manner, the market society attempts to homogenize and standardize the choices of the students, who are nourished with artificial and even means, preparing them to accept any need which is bound to be judged by this market society as worthy commodity. Reason, as critical analysis, no longer exists - it is replaced by the indiscriminate granting of power to authority. To the extent, indeed, that education in its ideal framework is a political and moral practice, this thoughtless concession cannot be considered as a democratic and ethical process.

Besides half education, the catalytic effect of entertainment as a mass culture, which now alters the quality of the overall educational product, is ascertained. When interpreting Adorno and Horkheimer, the power of cultural industry over the citizens - consumers comes from the connection of this industry to their induced needs. Entertainment is nothing but the continuation of their labor. Mechanization dominates the free time and human happiness so much and it so fundamentally determines the construction of leisure goods that the human being can only experience the replicas of the work process itself, as the content is the coating and what is engraved in memory is the automated succession of standardized actions ${ }^{4}$. Horkheimer observes in his essay Art and Mass Culture that this series of commonplace and repetitive actions, such as the manipulated pleasures (sport events, cinema, television, etc.), results in the

${ }^{1}$ Cf. Adorno Th., I theoria tis imimorfosis [Theory of "Half - education"], transl. L. Anagnostou, Alexandreia, Athens 2000.

2 Adorno Th., I theoria tis imimorfosis [Theory of "Half - Education"], transl. L. Anagnostou, Alexandreia, Athens 2000, p. 19.

3 Adorno Theodor \& Horkheimer Max, Dialektiki tou Diafotismou [Dialectic of Enlightenment], transl. L. Anagnostou, Nisos, Athens 1996, pp. 213 and 215.

${ }^{4}$ Adorno Theodor \& Horkheimer Max, Dialektiki tou Diafotismou [Dialectic of Enlightenment], transl. L. Anagnostou, Nisos, Athens 1996, pp. 227 - 228. 
annihilation of inner life. However, when one lacks the ability to resort to a private conceptual world, to an inner refuge, then one cedes his ability to conceive a world different from that in which one lives ${ }^{1}$. Hence, according to Adorno and Horkheimer in the Dialectic of Enlightenment, the viewer of mass culture in the modern world, which undertakes the responsibility of the daily education of citizens, is without access to his own perception. The product prescribes every reaction through signals, not through the structure of the content. Every reasonable correlation in the world of mass culture is assiduously ${ }^{2}$ avoided.

The present merging of culture and entertainment inevitably leads to the trivialization of culture, owing to the fact that culture is experienced only through effigies. Entertainment itself is regarded as ideal; it substitutes high goods, making the masses detach themselves from them completely. The inner world, where the subjectively restricted form of truth lies, becomes enslaved to external masters ${ }^{3}$. Additionally, in this contour of psychological and social reference, empirical life through symbolic expressions spread by entertainment products, is prevented by a kind of meaning that precludes any adequate experience. ${ }^{4}$ The very personal ability for life experiences is mitigated and each offered experience becomes fragmented and driven. In this way, the cultural problem turns into a pedagogical issue of ethical nature, focusing on addressing the psychological mechanisms that turn the individual into a spineless and passive human being.

In many ways, the basis of entertainment is human weakness. This basis is nothing but fleeing not only from reality, but also from the last thought for resistance that this reality has left for us. The liberation that entertainment promises is the deliverance, the emancipation from thought. Adorno and Horkheimer write in the Dialectic of Enlightement: "the shamelessness of the rhetorical question 'What do people want?' lies in the fact that it appeals to the very people as thinking subjects whose subjectivity it specifically seeks to annul" 5 .

By this means, the cultural industry classifies man as a being belonging to generality, as a sample of the genre. The person is a completely dispensable be-

\footnotetext{
${ }^{1}$ Adorno, Lowenthal, Marcuse, Horkheimer, Texni and maziki koultoura [Art and Mass culture], selection of texts and trasl. Z. Sarikas, Ipsilon, Athens 1984, pp. 54.

${ }^{2}$ Adorno Theodor \& Horkheimer Max, Dialektiki tou Diafotismou [Dialektik der Aufklarung], transl. L. Anagnostou, Nisos, Athens 1996, p. 228.

${ }^{3}$ Adorno Theodor \& Horkheimer Max, Dialektiki tou Diafotismou [Dialektik der Aufklarung], transl. L. Anagnostou, Nisos, Athens 1996, pp. 238 - 239.

${ }^{4}$ Kraus, Adorno, MacDonald, Arendt, Shils, Parsons, Williams, Morin, Baudrillard, I koultoura ton meson [The Culture of the Media], composition \& editing K. Livieratos \& $\mathrm{T}$. Fragkoulis, 3nd edition, Aleksandreia, Athens 1991, p. 106.

${ }^{5}$ Adorno Theodor \& Horkheimer Max, Dialektiki tou Diafotismou [Dialectic of Enlightenment], transl. L. Anagnostou, Nisos, Athens 1996, p. 240.
} 
ing without difference in the kind ${ }^{1}$. People, losing their subjectivity through the ideology of labor and consumption, become objects, as employees and consumers. The formal "freedom" of each object is, certainly, guaranteed. Nobody officially apologizes for what they think in the interior realm, inside themselves. Instead, they are incarcerated in a system of relationships and beliefs, which are served by institutional assemblies and constitute the most sensitive instrument of social control.

Ortega y Gasset, the Spanish philosopher who represents the philosophical movement of vitalism and perspectivism, upholds that the vulgar soul, the soul of the mass person, el hombre medio, while it is aware of its vulgarity, it proclaims, for itself, the right to vulgarity, and indeed imposes it everywhere ${ }^{2}$. Thus the different, the individual, the capable, the noble, are disregarded, ignored, or rejected. Whoever is not like "everybody else," whoever does not contemplate like "everybody else," is in danger of being trodden upon, by the horde of barbarians which is the mass. Ortega is not a devotee of aristocratism; he aims at analyzing how a society is deprived of its most essential potentialities if it does not seek within its core what constitutes the perfect and the noble.

The new masses find themselves in the presence of a prospect full of possibilities, and furthermore, quite secure, with everything ready to their hands, independent of any previous efforts on their part. Thus is explained and defined the absurd state of mind revealed by these masses; they are only concerned with their own well-being, and at the same time they remain alien to the cause of that well-being. ${ }^{3}$ This type of person, who belongs to the mass, psychologically is a "spoiled child" (nico mimado), since his desires are subjected to no restraint, but also due to the fact that he feels no gratitude for what he has under his possession. This, in consequence, makes him feel no obligation for anything and that he is allowed everything. He becomes an individualist because no collectivity seems necessary for him, ${ }^{4}$ other than his resemblance with the crowd. In this manner, he becomes isolated, trapped in the irrational feeling that nothing else, apart from his own private welfare, matters, but he also continues to demand as if it were his natural right to do so. Nonetheless, and although he remains an individualist, he does not have real access to the gifts of individuality.

${ }^{1}$ Adorno Theodor \& Horkheimer Max, Dialektiki tou Diafotismou [Dialectic of Enligtenment], transl. L. Anagnostou, Nisos, Athens 1996, p. 242. Cf. Adorno Theodor, Minima Moralia, transl. L. Anagnostou 2nd edition, Aleksandreia, Athens 2000, p. 107.

${ }^{2}$ Ortega y Gasset, Jose, La rebellion de las masas, Revista de Occidente en Alianza Editorial, Madrid 1979, p. 52.

${ }^{3}$ Ortega y Gasset, Jose, La rebellion de las masas, Revista de Occidente en Alianza Editorial, Madrid 1979, p. 87.

${ }^{4}$ Ortega y Gasset, Jose, La rebellion de las masas, Revista de Occidente en Alianza Editorial, Madrid 1979, p. 85. 
According to another representative of the Frankfurt School, Herbert Marcuse, instead of a humanization process, culture which is reproduced within education is not aimed at developing the mental skills of people. People express their opinion and move about, relatively freely, regarding finding a job or trade - but their opinions are characterized by passivity, never exceeding the established social system that determines not only their choices but, further, their views. As follows, such a culture renders the human subject one-dimensional and reinforces his dependency on external conditions and on his needs. For the recovery of intellectual freedom, it is essential to exceed public opinion as well as to restore individual thought, which today suffocates due to the media and is a victim of education ${ }^{1}$.

The German philosopher, in his essay Remarks on a Redefinition of Culture ${ }^{2}$ vehemently supports that the existing institutions and relationships among members of a certain society must present an evident affinity with the proclaimed values. They should in fact constitute a basis for the potential realization of these values. Therefore, the re-examination of a given culture is not a gnoseological problem, but a problem of social structure, provided that there is a visible link between the goals of a society, which are its values, and the means that are followed. So culture, as a superior dimension of human autonomy and fulfillment, as "the realm of freedom", characteristically Marcuse says, should be linked to the social act, i.e. work and behavior, which constitute "the realm of necessity". This connection to the modern civilization has taken place as violent and perverse integration of this altered culture in society. The gap between material culture and spiritual culture, between necessity and freedom, is bridged in an alienating and distorted manner. The technological culture tends to eliminate the transcendent purposes of culture, as well as the characteristics that compete with it. However, because of this, the chance to create a vital space for the development of human autonomy and antithesis, the only hindrances against totalitarianism and operationalization, is also eliminated ${ }^{3}$. For Marcuse, the person's self-determination signifies the person's critical manumission from the given world of experience. As a criticism on experience and as an extensive reference to education, self-determination is the exclusive means for a future society, as well as for a future rationality.

According to the German thinker, if mass culture fails to express the validity of the concepts of truth, freedom and justice in the oppressed experience of

${ }^{1}$ Marcuse Herbert, O monodiastatos antropos [One - Dimensional Man], transl. M. Lukoudi, Papazisi, Athens 1971, p. 36.

${ }^{2}$ Adorno, Lowenthal, Marcuse, Horkheimer, Texni and maziki koultoura [Art and Mass culture], selection of texts and trasl. Z. Sarikas, Ipsilon, Athens 1984, pp. 27 - 29.

${ }^{3}$ Adorno, Lowenthal, Marcuse, Horkheimer, Texni and maziki koultoura [Art and Mass culture], selection of texts and trasl. Z. Sarikas, Ipsilon, Athens 1984, pp. 30 - 31. 
human beings, in other words if it fails to lead to their social realization, education favoring autonomy will always be the privilege of the few. In accordance with Adorno and Horkheimer, at this particular point, Marcuse believes that the reckless production is simultaneously a disaster, and the rational knowledge which favors (as a background) this production, is nothing but ignorance or Heideggerian care (Sorge). Marcuse understands that there is a conflict between production and profit on the one hand and self-determination on the other. At the same time, as the technology spreads its dominance over nature, man conquers man through mass control, diffused through work and culture. In this way, technological rationalism becomes ultimately political rationalism. Through technology, education, politics, economy are mixed together in a system that repels any counter-trend ${ }^{1}$. So the necessary a priori of liberation of a superintended society is lost; which is nothing more than the free intellect ${ }^{2}$. In contrast with Adorno and Horkheimer, who defend the "specific negation" as a search of meditations in politics and education, Marcuse takes the position of the "great negation", as tension between the individual and the universal, in favor of the authentic autonomy of the individual and of the authentic liberation of society ${ }^{3}$.

Marcuse develops two fundamental understandings in relation to education, which he does not usually refer to directly: primarily the need for the production of a social criticism and secondarily, the concern about the radical change of the human needs ${ }^{4}$. Similarly, knowledge, thought, reason are the catalysts for social change. Since there is not a general education, he asserts that educational inequality is an expression of social inequality ${ }^{5}$. The dialectic of education, as formulated in modern society, according to Marcuse, indicates a growing reliance on the knowledge inside the competitive economic mainstream. On a parallel level, it denotes the need to enclose reason and knowledge within the conceptual and value system of society in such a way so as to lead to the preservation of society and to avoid fundamental change. Hence, both humanities and critical thinking are circumvented ${ }^{6}$. Marcuse clarifies that

\footnotetext{
${ }^{1}$ Marcuse Herbert, $O$ monodiastatos antropos [One - Dimensional Man], transl. M. Lukoudi, Papazisi, Athens 1971, p. 29.

${ }^{2}$ Marcuse Herbert, O monodiastatos antropos [One - Dimensional Man], transl. M. Lukoudi, Papazisi, Athens 1971, p. 251.

${ }^{3} \mathrm{Cf}$. Lamprellis Dimitris, I agonia tis arnisis ston Marcuse [The anxiety of negative in Marcuse], Papazisi, Athens 2012.

${ }^{4}$ DeVitis J., "Marcuse on education: social critique and social control". In Educational Theory, 24, 1974, p. 259.

${ }^{5}$ Kellner Doug, Tyson Lewis, Clayton Pierce, and Daniel Cho (eds.), Marcuse's Challenge to Education, Rowman \& Littlefield Publishers, Plymouth 2009, p. 33-34.

${ }^{6}$ Kellner Doug, Tyson Lewis, Clayton Pierce, and Daniel Cho (eds.), Marcuse's Challenge to Education, Rowman \& Littlefield Publishers, Plymouth 2009, p. 34.
} 
in order to create the subjective conditions of a free society, creating individuals who only perform the functions of that society is not sufficient. On the contrary, it is imperative to exceed vocational training in the direction of the education of people who are not willing to tolerate what is happening in the modern world, and who are prepared to resist in order to create a new world. So, education escapes from the confinement of the classroom, addressing the modern man with a political and moral vocabulary, with a view to the application of knowledge for the improvement of his life ${ }^{1}$.

In conclusion, to exceed modern barbarity which is strengthened through the catalytic dispersion of the dominant mass culture in the social body, Adorno - Horkheimer and Marcuse advocate the shaping of pedagogical action as an instrument that will promote the autonomy of the human spirit, in historical and individual-subjective level. According to the representatives of the Frankfurt School, the loss of critical thinking in favor of a society of production and objectification of the human factor constitutes catalysis and violation of the basic historical parameters set by the phenomenon of human existence on the planet. The resolution to the above problem is provided by maintaining the personal element. The person, the subjectification of reality, the uniqueness of individual consciousness, offers an exit from totalitarianism and access to freedom. As Adorno conclusively remarks: "He who offers for sale something unique (Unikum) that no - one wants to buy, represents, even against his will, freedom from exchange" 2 . To make this accessible to all, the following are necessary: activity through knowledge, consciousness, and autonomy of the spirit as well as the understanding of the psychological and social ties. In the words of Marcuse who asserts emphatically that truth: "All liberation depends on the consciousness of servitude" ${ }^{3}$

\section{Bibliography:}

1. Adorno Theodor, Minima Moralia, transl. L. Anagnostou, $2^{\text {nd }}$ edition, Alexandreia, Athens 2000.

2. Adorno Theodor, I theoria tis imimorfosis [Theory of "Half - Education"], transl. L. Anagnostou, Alexandreia, Athens 2000.

3. Adorno Theodor \& Horkeheimer Max, Dialektiki tou Diafotismou [Dialectic of Enlightenment], transl. L. Anagnostou, Nisos, Athens 1996.

4. Adorno, Lowenthal, Marcuse, Horkheimer, Texni kai maziki koultoura [Art and Mass culture], selection of texts and transl. Z. Sarikas, Ipsilon, Athens 1984.

${ }^{1}$ Kellner Doug, Tyson Lewis, Clayton Pierce, and Daniel Cho (eds.), Marcuse's Challenge to Education, Rowman \& Littlefield Publishers, Plymouth 2009, p. 35.

${ }^{2}$ Adorno Theodor, Minima Moralia, transl. L. Anagnostou, 2nd edition, Aleksandreia, Athens 2000, I. 41.

${ }^{3}$ Marcuse Herbert, $O$ monodiastatos anthropos [One - Dimensional Man], transl. M. Lukoudi, Papazisi, Athens 1971, I. 1. 
5. DeVitis Joseph, "Marcuse on education: social critique and social control". In Educational Theory, 24, 1974, pp. $259-268$.

6. Kellner Doug, Tyson Lewis, Clayton Pierce, and Daniel Cho (eds.), Marcuse's Challenge to Education, Rowman \& Littlefield Publishers, Plymouth 2009.

7. Kraus, Adorno, MacDonald, Arendt, Shils, Parsons, Williams, Morin, Baudrillard, I koultoura ton meson [The Culture of the Media], compilation \& editing K. Livieratos \& T. Fragkoulis, 3nd edition, Aleksandreia, Athens 1991.

8. Lamprellis Dimitris, I agonia tis arnisis ston Marcuse [The anxiety of negative in Marcuse], Papazisi, Athens 2012.

9. Marcuse Herbert, O monodiastatos anthropos [One - Dimensional Man], transl. M. Lukoudi, Papazisi, Athens 1971.

10. Ortega y Gasset, Jose, La rebellion de las masas, Revista de Occidente en Alianza Editorial, Madrid 1979.

\section{Панос Eліопулос. Масова культура, освіта та перспективи індивідуальності}

Згідно з Адорно і Горкгаймером, раціоналізм - а насправді технічний раціоналізм, який стає раціоналізмом домінування - не зміг вказати шлях до звільнення людини і суспільства. Як наслідок, напівосвіченість мас не є неповною освітою або відсутністю освіти, а є по суті ворожим по відношенню до культури і справжньої освіти розкладанням і використанням освіти на догоду окремим міркуванням і вигодам, у міру масового поширення культури і мистецтва. Напівосвіченість є поширенням культури і мистецтва без живих відносин зі свідомістю людей, без наслідків для їхнього життя. Адорно пояснює, що в цьому контексті відносини між життям і виробництвом зводяться до того, що перше являє собою тимчасовий епіфеномен останнього, а оскільки життя і індивідуальне існування не відомі у своїй безпосередній даності, то зв'язок між ними і виробництвом не є безпосереднім, і вони, по суті, стають частиною навчання для матеріального виробництва.

Згідно з Ортегою-і-Гассетом, народжується новий тип людини, масова людина, яка стає ізольованою, зануреною в ірраціональні відчуття того, що більше ніщо, крім її власного благополуччя, не має значення, але при цьому вона продовжує висувати вимоги так, як ніби має на це природне право. Проте, хоча вона і залишається індивідуалізованою, вона не має реального доступу до благ індивідуальності. Маркузе зрозумів, що, в кінцевому рахунку, має місце конфлікт між виробництвом і прибутком, з одного боку, i самовизначенням, з іншого боку. У міру того, як технологія розширює своє панування над природою, людина підпорядковує людину за допомогою масового контролю, що проникає через роботу і культуру. Таким чином, технологічний раціоналізм, в кінці кінців, стає політичним раціоналізмом.

Ключові слова: Адорно, Горкгаймер, Ортега-і-Гассет, Маркузе, масова культура, виробництво, освіта, індивідуальність. 
Панос Элиопулос. Массовая культура, образование и перспективы индивидуальности

Согласно Адорно и Хоркхаймеру, рационализм - а на деле технический рационализм, который становится рационализмом доминирования - не смог предоставить путь к освобождению человека и общества. Как следствие, полуобразованность масс не представляет собой неполное образование или отсутствие образования, а по существу является враждебным по отношению к культуре и подлинному образованию разложением и использованием образования в угоду отдельным соображениям и выгодам, по мере массового распространения культуры и искусства. Полуобразованность является распространением культуры и искусства без живых отношений с сознанием людей, без последствий для их жизни. Адорно поясняет, что в этом контексте отношения между жизнью и производством низводятся до того, что первая представляет собой преходящий эпифеномен последнего, а поскольку жизнь и индивидуальное существование не известны в своей непосредственной данности, то связь между ними и производством не является непосредственной, и они, по сути, становятся частью обучения для материального производства.

Согласно Ортеге-и-Гассету, рождается новый тип человека, массовый человек, который становится изолированным, погруженным в иррациональные ощущения того, что больше ничто, кроме его собственного благополучия, не имеет значения, но при этом он продолжает выдвигать требования так, как будто имеет на это естественное право. Тем не менее, хотя он и остается индивидуалистом, он не имеет реального доступа к благам индивидуальности. Маркузе понял, что, в конечном счете, имеет место конфликт между производством и прибылью, с одной стороны, и самоопределением, с другой стороны. По мере того, как технология расширяет свое господство над природой, человек подчиняет человека посредством массового контроля, проникающего через работу и культуру. Таким образом, технологический рационализм, в конце концов, становится политическим рационализмом.

Ключевые слова: Адорно, Хоркхаймер, Ортега-и-Гассет, Маркузе, массовая культура, производство, образование, индивидуальность

Panos Eliopoulos, PhD, Prof., University of Peloponnese, Greece.

E-mail: ksatriya@tri.forthnet.gr

Панос Еліопулос, доктор філософії, професор, Університет Пелопоннесу, Греція. 